\title{
Effect of Gibberellin and Ethephon on Growth and Yield of Bread Wheat Grown in Different Sowing Dates
}

\author{
Khudhair Abbas Jaddoa ${ }^{1}$, Ayad Hussein AL-Maeini' ${ }^{2}$, Raisan Ahmed AL-Zobiady ${ }^{2}$ \\ ${ }^{1}$ University of Baghdad, College of Agriculture, Department of Field Crop Sciences, Baghdad, Iraq \\ ${ }^{2}$ Al-Qasim Green University, College of Agriculture, Department of Field Crop Sciences, Babil, Iraq
}

\section{Email address:}

dr.ayad24@yahoo.com (A. H. Al-Maeini),Khdhayerjaddoa@yahoo.com (K. A. Jaddoa), risan1987.87@gmail.com (R. A. Al-Zobiady)

\section{To cite this article:}

Khudhair Abbas Jaddoa, Ayad Hussein AL-Maeini, Raisan Ahmed AL-Zobiady. Effect of Gibberellin and Ethephon on Growth and Yield of Bread Wheat Grown in Different Sowing Dates. International Journal of Applied Agricultural Sciences. Vol. 3, No. 5, 2017 , pp. 136-142. doi: $10.11648 /$ j.ijaas.20170305.15

Received: August 2, 2017; Accepted: August 14, 2017; Published: September 26, 2017

\begin{abstract}
A field trial was conducted in a private farm at AL-Hilla, Iraq during the growing season 2014-2015. The objective of this study was to investigate the foliar application of ethephon and gibberellin on growth and yield of wheat (Triticum aestivum L.) cultivar Iba.99 planted in different dates. Results of this experiment revealed that: application of ethephon $\left(\mathrm{GR}_{2}\right)$ caused a significant increase in grain yield (an average) of $3.754 \mathrm{t} \mathrm{ha}^{-1}$ due to its superiority in one of the main components (number of spike. $\mathrm{m}^{-2}$ ) which was amounted to 328.25 spike $\mathrm{m}^{-2}$ as a result of increased number of tillers (377.18 tiller $\left.\mathrm{m}^{-2}\right)$. However, gibberellin $\left(\mathrm{GR}_{1}\right)$ had significant increase in the weight of thousand grain $(38.26 \mathrm{~g})$. Planting date in November 18 (D3) significantly increased the grain yield to 5.25 tons. ha ${ }^{-1}$ due to high values of grain yield components. Most growth traits, were reflected in an increased biological yield. There was a significant interaction between planting dates and plant growth regulators (ethephon and gibberellin) in all traits, except spike length.
\end{abstract}

Keywords: Gibberellin, Ethephon, Sowing Date, Growth, Grain Yield, Bread Wheat

\section{Introduction}

Variation in yield and quality can occur because of variation in genetics, soil, weather and other growing conditions [1]. Planting date is the key of successful wheat management which is important to maximize yield, when planting too early or too late reduces yield potential [2] [3]. The seasonal sequence of condition play a major role in determining whether source (photosynthesizing organs) or sink (storage organs) is more limiting [4] [5]. In any crop plant when source and sink developed simultaneously the adjustment of these two component may be more readily achieved [6]. Planting date plays a vital role in adjusting the balance between source and sink [7], The optimum window for wheat planting date in the middle region of Iraq is typically from mid November to mid December [8] [9], but planting during this period can not be always controlled. Sometimes, there is a need to plant wheat earlier than the optimum date due to the irrigation scheduling among the farmers which extend the intervals of irrigation to insure fair distribution of water. In other time the early fall of rain (beginning of November) makes machines movement more difficult due to the high soil moisture content which delay planting, therefore, there is a need to plant wheat earlier.

Tillering the increase in the number of stem developed form a single plant is the most critical component for wheat yield. Early planting results in a decreased tillering due to high temperature and apical dominance of main shoot which inhibit axillar buds growth [10]. Many studies conducted on major crops such as wheat, rice, corn and soybean have identified materials capable of tillering individual agronomic characteristics like tillering, lodging, plant height, seeds number and maturity [11]. [12] investigated the exogenous hormones (GA3, IAA....e.t.c ) to regulate the population structure, tiller initiation, growth and uniformity of tillers in wheat. It was found that release of ethyllen in plant tissue stimulates growth of lateral tiller buds from inhibition of apical dominance (main shoot) by retarding auxin action of elongation the main stem [13] [11]. For example, foliar 
treatments included chlormequat (CCC) at $2.20 \mathrm{~kg}$. ha ${ }^{-1}$ sprayed over the foliage at growth stages ZGS 25 [14], and ethephon at $0.28 \mathrm{~kg}$. ha ${ }^{-1}$ sprayed over the foliage at growth stage ZGS 39 could increase number of tillers and then number of spike per $\mathrm{m}^{2}$ [15]. The objectives of this research were to investigate the effect of application of PGRs (ethephon and gibberellin) on growth, yield and the yield components of wheat (cv. Iba-99) when planting earlier than the optimal date under the middle region of Iraq conditions.

\section{Materials and Methods}

To investigate the influences of plant growth regulators (PGRs) on growth, yield and its components of early planted wheat,a field experiment was conducted at a private (within latitude $32^{\circ} 31^{\prime}$ north and longitude $44^{\circ} 21^{\prime}$ eastwards) belong to ALfayha company in Annana region, Hilla, Babil, Iraq during the season 2014-2015. Soil of experiment was ploughed twice by using mould board plough, cultivated by disc harrow and leveled.

The soil in this area was a silt clay loam with average SOM of 4.6 gm. $\mathrm{kg}^{-1}$, N 71.4 gm. kg ${ }^{-1}$, P 11.7 gm. $\mathrm{kg}^{-1}$, K 279.0 gm. $\mathrm{kg}^{-1}, \mathrm{PH} 7.18$ and Ec $3.02 \mathrm{ds}^{-1} \mathrm{~m}^{-1}$.

The experiment was laid out in a randomized complete block design with a split-plot arrangement and three replicates, plot was $3 \mathrm{~m} \times 4 \mathrm{~m}$. The experimental plot fertilized with $200 \mathrm{~kg} \mathrm{~N}$. ha ${ }^{-1}$ as urea $(46 \% \mathrm{~N})$ Which divided in four equal payments (buried with per sowing, The emergence of three full leaves, 2 nd nods and at the booting stage) and phosphate $\left(45 \% \mathrm{P}_{2} \mathrm{O}_{5}\right)$ buried per sowing. A spring wheat cultivar (Iba-99) was chosen as a in common the region it was drilled in $15 \mathrm{~cm}$ spaced at a seed rate of $140 \mathrm{~kg} \cdot \mathrm{ha}^{-1}$ (according to planting dates) of experiment. The factors included three planting dates (October $18\left(\mathrm{D}_{1}\right)$, November 3 $\left(\mathrm{D}_{2}\right)$ and November $18\left(\mathrm{D}_{3}\right)$ as a main plots. Four growth regulators foliar treatments including $\mathrm{GR}_{0}$ (sprayed with distilled water as a control), $\mathrm{GR}_{1}$ (sprayed with gibberellic acid at $250 \mathrm{mg} . \mathrm{L}^{-1}$ ), $\mathrm{GR}_{2}$ (sprayed with ethephon at 0.420 gm. ha ${ }^{-1}$ as solution with distilled water) and $\mathrm{GR}_{3}$ (sprayed with ethephon after two weeks from gibberellin spraying). The spraying of this treatment was done by handling sprayer (vol. $18 \mathrm{~L}$ ) in the early morning over the foliage at growth stage ZGS23. Weeding is done and irrigation scheduling is managed according to soil moisture content. At anthesis, fifteen plants per sub-plot were randomly sampled to measure plant height, number of tiller, flag leaf area and its dry weight, spike length.

At harvest maturity fifteen plants per sub-plot were sampled to determine, number of spikelet per spike, number of kernel per spike and 1000 kernel weight. A sample area of $2 \mathrm{~m}^{2}$ (the center three rows of each plot) was hand harvested and the mass of plants and grain were determined on 15 may 2015. The samples were threshed to grain and straw. grain yield was calculated as a weight of grain of $2 \mathrm{~m} 2$ and then converted to $\mathrm{kg}$ per hectare.

All data were analyzed by using the SPSS 12.0 statistical software package and least significant difference (LSD) test were used at $\mathrm{P}=0.05$.

\section{Results}

\subsection{Growth Parameters}

Varying planting dates and growth regulators had significant effects on above ground dry matter (biomass) accumulation (DM), crop grow ration (CGR) and relative growth ration (RGR).

Planting date $\left(D_{1}\right)$ produced greater dry matter $(D M)$ after of and go days of sowing than the $\mathrm{D}_{2}$ and $\mathrm{D}_{3}$ while after 110 , 130 , and 150 days, $D_{3}$ produced greater than $D_{1}$ and $D_{2}$. Spraying with gibberellin $\left(\mathrm{GR}_{1}\right)$ only produced a greater dry matter (DM) with on significant differences with ethephon + gibberellin $\left(\mathrm{GR}_{3}\right)$. Combination $\mathrm{D}_{3} \times \mathrm{GR}_{2}$ produced a highest biomass after 150 days of planting dates.

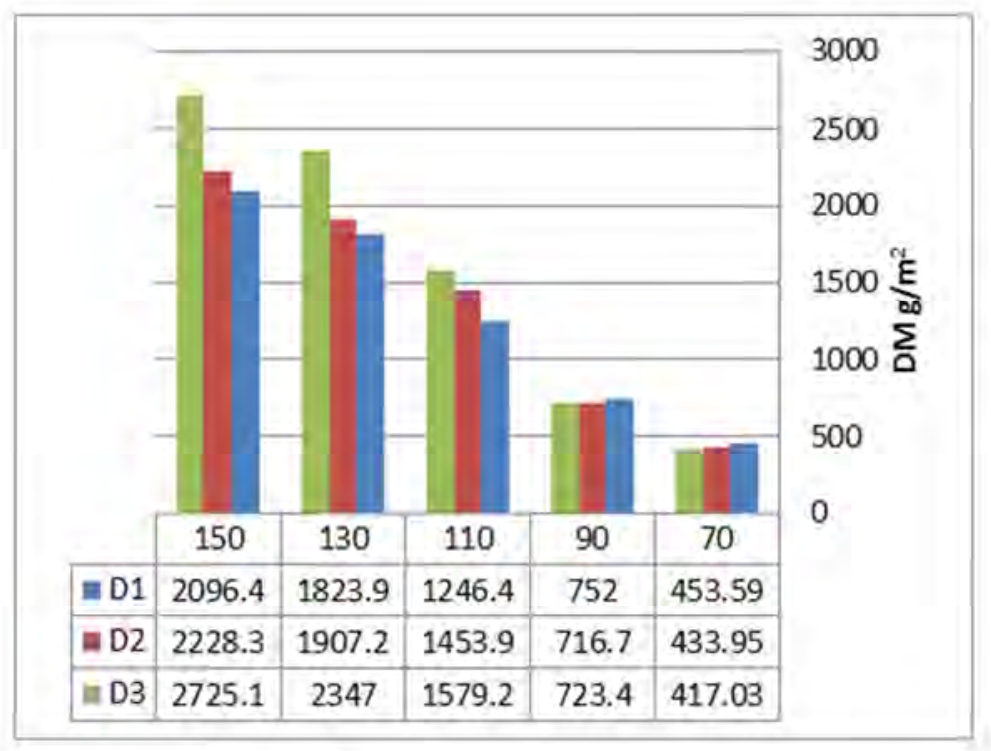

Figure 1. Effect of planting dates on DM. 


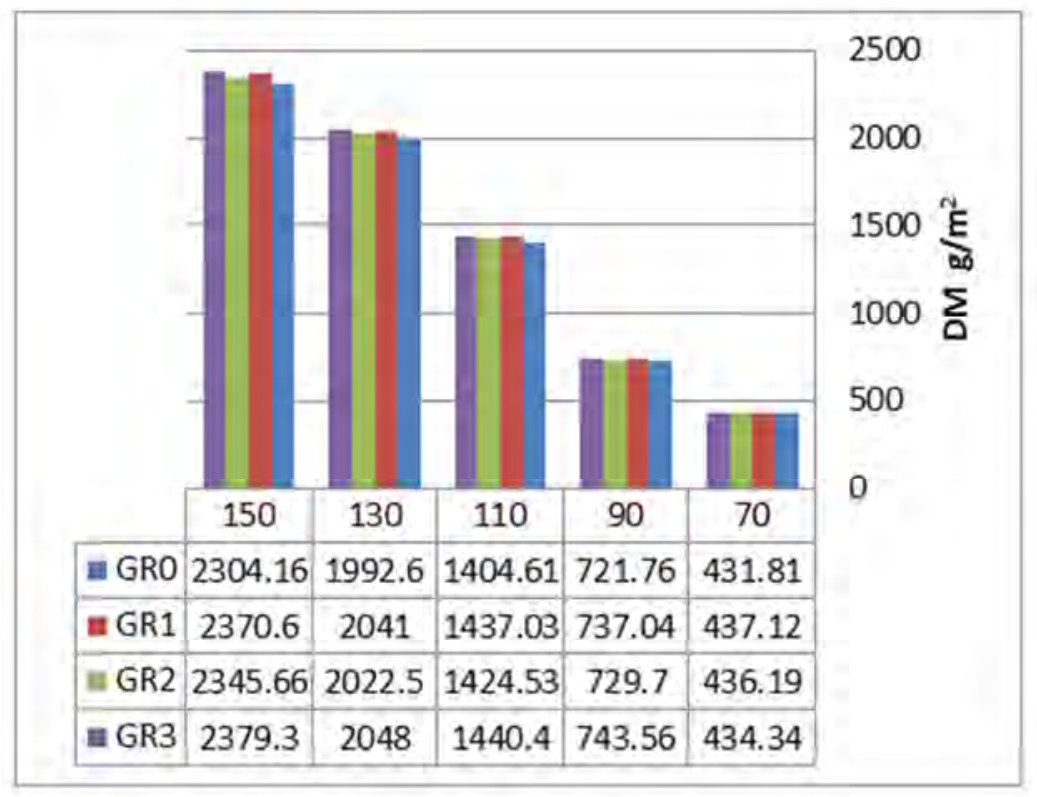

Figure 2. Effect of PGR on DM.

The results shows that CGR was little of the primary periods of growth. then it increased and reached the peak at 90-110 days for $\mathrm{D}_{2}$ and $\mathrm{D}_{3}$ while the $\mathrm{D}_{1}$ plant was late to 110 130 days to reach the peak. $\mathrm{D}_{2}$ gave a highest CGR at 70-90 days while $\mathrm{D}_{3}$ gave a highest CGR at 90-110, 110-130 and 130-150 days compared with $\mathrm{D}_{1}$. Et $\times \mathrm{D}_{3}$ gave a highest CGR at $90-110$ days.

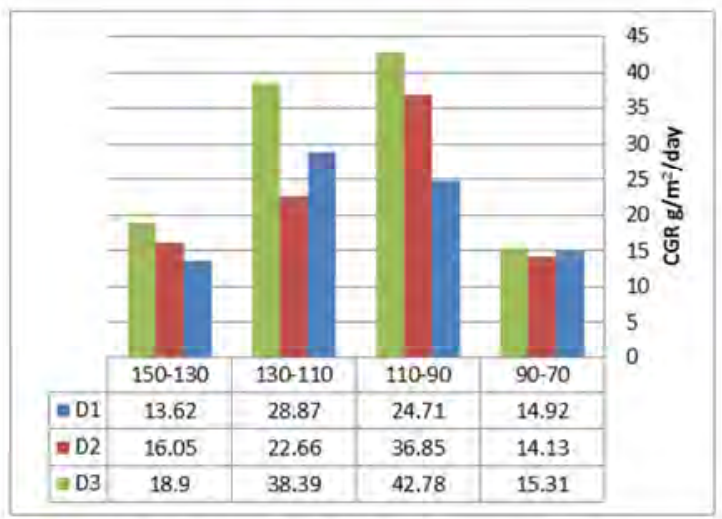

Figure 3. Effect of planting dates on CGR.

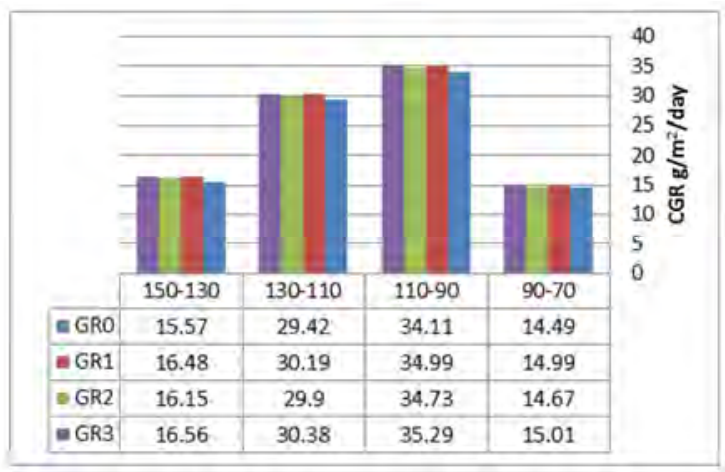

Figure.4. Effect of PGR dates on CGR.
Plants of $\mathrm{D}_{3}$ gave a highest RGR at 90-110, 110-130 and 130-150 days compared with $\mathrm{D} 1$ and $\mathrm{D}_{2}$, while the $\mathrm{D}_{2}$ gave a highest RGR at 130-150 days.

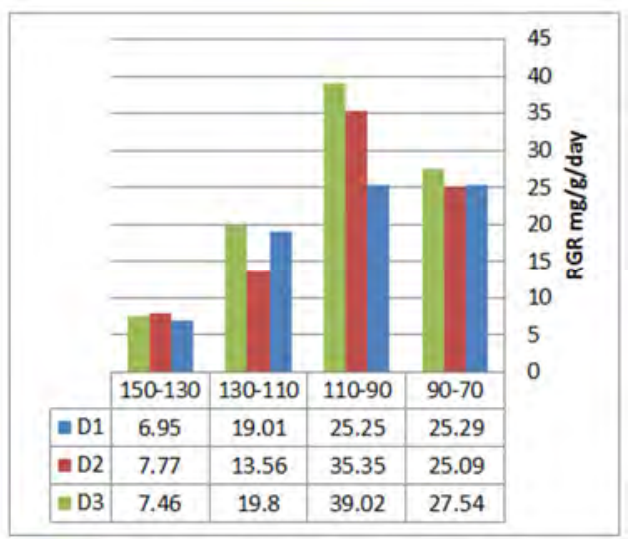

Figure 5. Effect of planting dates on RGR.

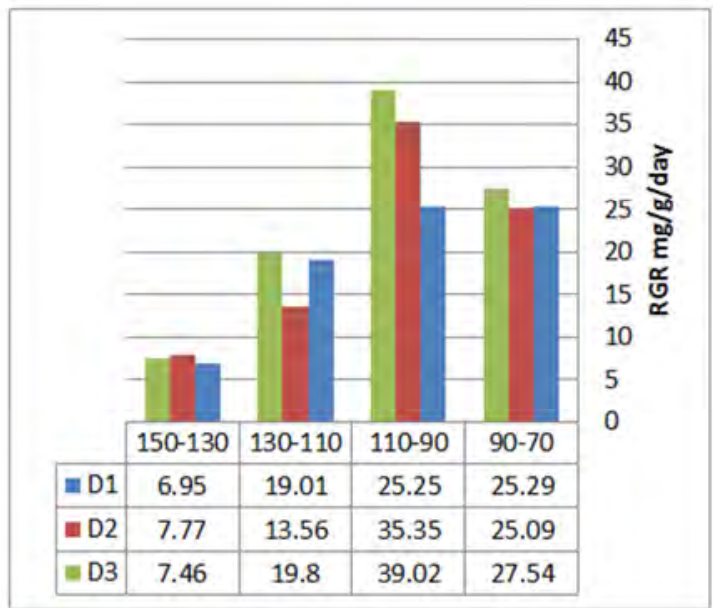

Figure 6. Effect of PGR on RGR. 


\subsection{Vegetation Indices}

Plant height was maximum in $\mathrm{D}_{1}(105.68 \mathrm{~cm})$, while late dates $\left(D_{2}\right.$ and $\left.D_{3}\right)$ and cause of the delay from this date $\left(D_{1}\right)$ shorthand in plant height were percentage of $4.2 \%$ and $12.4 \%$ respectively. Spraying with gibberellin $\left(\mathrm{GR}_{1}\right)$ and ethephon + gibberellin $\left(\mathrm{GR}_{3}\right)$ caused increase with plant height by $4.5 \%$ and $3.6 \%$ to control. $\mathrm{GR}_{3} \mathrm{X} \mathrm{D}_{1}$ gave a highest plant height $(117.28 \mathrm{~cm})$.

Early planting date $\left(\mathrm{D}_{1}\right)$ gave lesser tiller $\left(270.02\right.$ tiller.m $\left.{ }^{2}\right)$, while $\mathrm{D}_{2}$ and $\mathrm{D}_{3}$ increased by $34 \%$ and $57 \%$ on $\mathrm{D}_{1}$ respectively. The highest number of tillers was obtained with spraying ethephon only (377.1 tiller.m $\left.{ }^{-2}\right)$. There was no effects of $\left(\mathrm{GR}_{1}\right)$ and $\left(\mathrm{GR}_{3}\right)$ treatment on number of tillers. there was a greater tillers number (477.14 tiller. $\mathrm{m}^{-2}$ ) from $\mathrm{GR}_{3}$.
The greater flag leaf area $\left(48.21 \mathrm{~cm}^{2}\right)$ and its dry weight $(0.53 \mathrm{gm})$ were recorded in $\mathrm{D}_{3}$, while the $\mathrm{D}_{1}$ was the fewest. Spraying with gibberellin $\left(\mathrm{GR}_{1}\right)$ caused increase of flag leaf area $\left(53.56 \mathrm{~cm}^{2}\right)$ and its dry weight $(0.60 \mathrm{gm})$ followed by $\mathrm{GR}_{3}$. It was obtained at the highest flag leaf area and flag leaf weight of interaction in $\mathrm{GR}_{3} \times \mathrm{D}_{3}$ amounted $57.48 \mathrm{~cm}^{2}$ and 0.67 g sequentially.

The results shows that lowest spike length was in $D_{1}$ $(11.04 \mathrm{~cm})$, spike length was increased with late of planting date by $7.8 \%\left(\mathrm{D}_{2}\right)$ and $13.2 \%\left(\mathrm{D}_{3}\right)$ compared with $\mathrm{D}_{1}$. Spraying of ethephon+ gibberellin $\left(\mathrm{GR}_{3}\right)$ caused increase with spike length $(12.13 \mathrm{~cm})$ and by $5.9 \%$ on the control. It was not interaction significant effect in spike length.

Table 1. Effect of sowing dates and PGR (ethephon and gibberellin) on plant height (cm), no. of tiller.m-2,flag leaf area(FLA)(cm), flag leaf dry weigh $(F L D W)(g)$ and spike length $(\mathrm{cm})$.

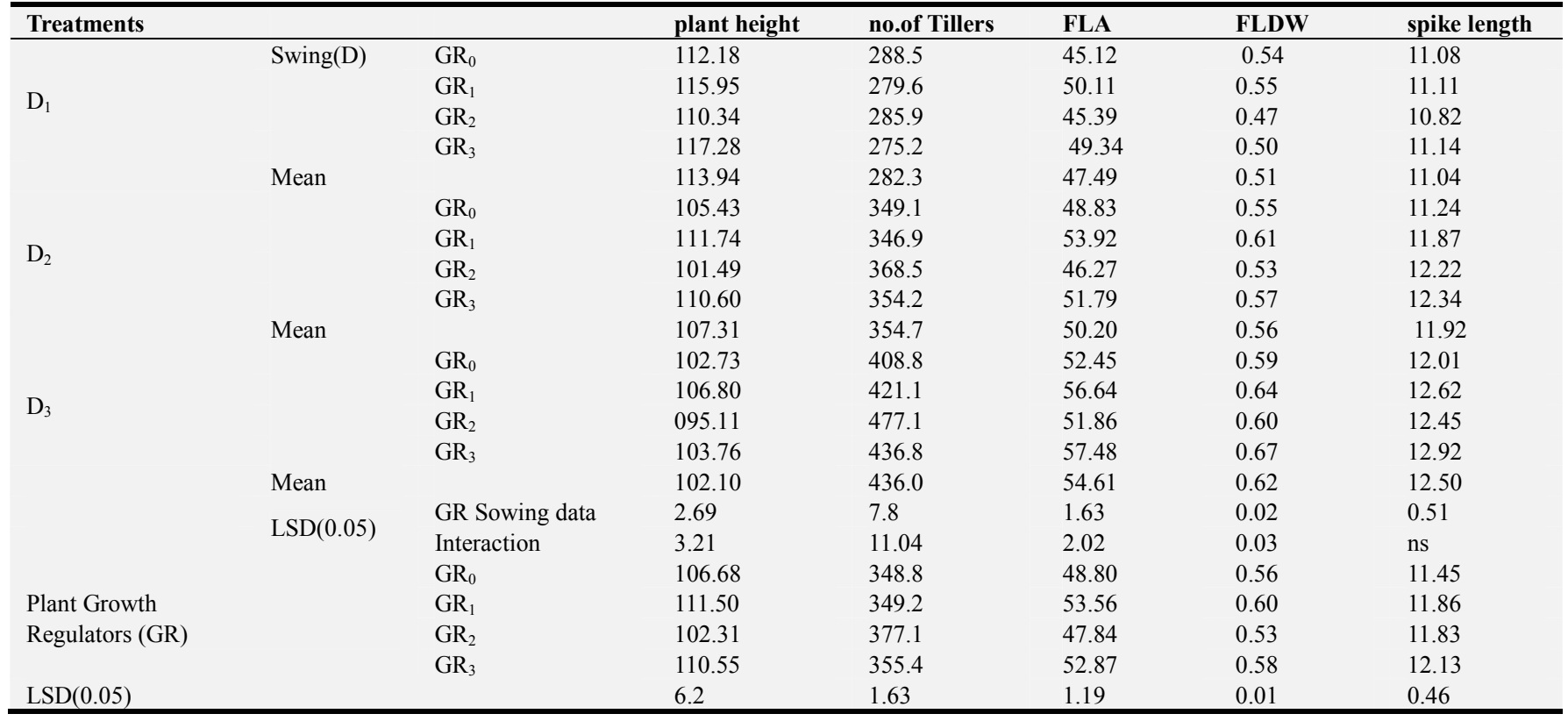

\subsection{Grain Yield and Its Components and Biological Yield}

Early planting date $\left(D_{1}\right)$ gave lesser number of spikes (257.63 spike. $\mathrm{m}^{-2}$ ), while $\mathrm{D}_{2}$ and $\mathrm{D}_{3}$ increased it by $18 \%$ and $24.47 \%$ over $D_{1}$, respectively. Ethephon $\left(G_{2}\right)$ caused a significant increase in the number of spikes at an average of 328.25 spike. $\mathrm{m}^{-2}$ by an increase of $9.2 \%$ compared with nontreated plants $\left(\mathrm{GR}_{0}\right)$, followed by ethephon + gibberellin $\left(\mathrm{GR}_{3}\right)$, which increased it by $2.1 \%$. Interaction of $\mathrm{GR}_{3} \mathrm{X} \mathrm{D}_{3}$ gave the highest number of spikes 402.59 spike. $\mathrm{m}^{-2}$.

$\mathrm{D}_{3}$ gave the highest average number of grains 46.91 grain. spike $^{-1}$, while (D1) gave the less 37.44 grain. spike ${ }^{-1}$ with a reduction of $20.1 \%$ and $15.3 \%$ from $\mathrm{D}_{3}$ and $\mathrm{D} 2$,respectively. None significant effect of growth regulators on the number of grain. spike ${ }^{-1}$ was found. $\mathrm{GR}_{3} \times \mathrm{D} 3$ gave the highest number of grains (59.36 grain. spike ${ }^{-1}$ ).

Third date $\left(\mathrm{D}_{3}\right)$ caused a significant increase in the grain weight $(40.41 \mathrm{~g})$, while the first date $\left(\mathrm{D}_{1}\right)$ gave the less weight of the grain $(33.95 \mathrm{~g})$. Spraying gibberellin $\left(\mathrm{GR}_{1}\right)$ caused a significant increase in the weight of grain $(38.26 \mathrm{~g})$ by $5.4 \%$ over control. The highest mean of grain weight $42.28 \mathrm{~g}$ resulted from $\mathrm{GR}_{2} \times \mathrm{D}_{3}$ interaction.

Date of early planting $\left(\mathrm{D}_{1}\right)$ gave lower grain yield $(1.98 \mathrm{t}$. $\left.\mathrm{ha}^{-1}\right)$. There was increase by $47.1 \%$ for $\left(\mathrm{D}_{2}\right)$ and $95.3 \%$ for $\left(\mathrm{D}_{3}\right)$. A greater grain yield was for ethephon $\left(3.77 \mathrm{t} . \mathrm{ha}^{-1}\right)$ with an increase of approximately $9.8 \%$ over control. A highest grain yield was obtained from $\mathrm{GR}_{2} \times \mathrm{D}_{3}$ interaction (5.77 t. ha $\left.{ }^{-1}\right)$.

The date of the third of planting $\left(\mathrm{D}_{3}\right)$, gave the highest biological yield and harvest index. They were 13.63 t. ha-1 and $27.03 \%$, respectively. Spraying with $\mathrm{GR}_{3}$ gave a highest biological yield (13.13 t. ha-1) and harvest index (28.43\%). There were no significant differences for $\mathrm{GR}_{1}$ and $\mathrm{GR}_{2}$. The highest biological yield $14.73 \mathrm{t}$ ha resulted from the interaction $\mathrm{GR}_{2} \times \mathrm{D}_{3}$. 
Table 2. Effect of sowing dates and PGR (ethephon and gibberellin) on No. of spikes. $m^{-2}$ No. of grains. spike $e^{-1}$ Grain weithg(g), Grain yield (t. ha $\left.{ }^{-1}\right)$ and Biological yield $\left(t . h a^{-1}\right)$.

\begin{tabular}{|c|c|c|c|c|c|c|c|}
\hline Treatments & & & no.of spikes & no.of grains & Grain weight & Grain yield & Biological yield \\
\hline \multirow{4}{*}{$\mathrm{D}_{1}$} & \multirow[t]{4}{*}{ Swing(D) } & $\mathrm{GR}_{0}$ & 264.37 & 41.26 & 32.17 & 2.28 & 11.60 \\
\hline & & $\mathrm{GR}_{1}$ & 255.26 & 41.03 & 36.66 & 2.32 & 11.70 \\
\hline & & $\mathrm{GR}_{2}$ & 261.27 & 42.37 & 32.52 & 2.28 & 11.52 \\
\hline & & $\mathrm{GR}_{3}$ & 249.91 & 40.21 & 34.46 & 2.27 & 11.81 \\
\hline \multirow{6}{*}{$\mathrm{D}_{2}$} & \multirow[t]{5}{*}{ Mean } & & 257.63 & 41.22 & 33.95 & 2.28 & 11.65 \\
\hline & & $\mathrm{GR}_{0}$ & 297.67 & 46.38 & 36.33 & 3.22 & 12.37 \\
\hline & & $\mathrm{GR}_{1}$ & 269.64 & 44.52 & 39.96 & 3.14 & 12.79 \\
\hline & & $\mathrm{GR}_{2}$ & 320.89 & 44.08 & 34.46 & 3.27 & 12.43 \\
\hline & & $\mathrm{GR}_{3}$ & 301.76 & 43.63 & 37.28 & 3.09 & 12.90 \\
\hline & \multirow[t]{5}{*}{ Mean } & & 304.00 & 45.15 & 37.01 & 3.18 & 12.62 \\
\hline \multirow{7}{*}{$\mathrm{D}_{3}$} & & $\mathrm{GR}_{0}$ & 339.35 & 53.24 & 41.62 & 4.79 & 14.19 \\
\hline & & $\mathrm{GR}_{1}$ & 356.63 & 59.36 & 39.83 & 5.31 & 14.52 \\
\hline & & $\mathrm{GR}_{2}$ & 402.59 & 50.62 & 42.28 & 5.77 & 14.73 \\
\hline & & $\mathrm{GR}_{3}$ & 369.62 & 57.79 & 36.88 & 5.13 & 14.68 \\
\hline & Mean & & 367.05 & 55.25 & 40.41 & 5.25 & 14.53 \\
\hline & \multirow{2}{*}{$\operatorname{LSD}(0.05)$} & GR Sowing data & 5.87 & 2.01 & 1.64 & 0.51 & 0.20 \\
\hline & & Interaction & 10.34 & 4.08 & 2.93 & 0.56 & 0.53 \\
\hline \multirow{4}{*}{$\begin{array}{l}\text { Plant Growth } \\
\text { Regulators (GR) }\end{array}$} & & $\mathrm{GR}_{0}$ & 300.46 & 46.96 & 36.71 & 3.43 & 12.72 \\
\hline & & $\mathrm{GR}_{1}$ & 302.84 & 48.31 & 39.15 & 3.59 & 13.00 \\
\hline & & $\mathrm{GR}_{2}$ & 328.25 & 46.36 & 36.42 & 3.77 & 12.89 \\
\hline & & $\mathrm{GR}_{3}$ & 306.97 & 47.21 & 36.20 & 3.49 & 13.13 \\
\hline $\operatorname{LSD}(0.05)$ & & & 5.81 & $\mathrm{Ns}$ & 1.80 & 0.25 & 0.31 \\
\hline
\end{tabular}

\section{Discussion}

The greater grain yield in the $\mathrm{D}_{3}$-planting date compared with $D_{1}$ and $D_{2}$ in this study was attributed to the increase of yield components (no. of spike. $\mathrm{m}^{-2}$, no. of grain. Spike -1 and grain weight) as shown in Table (2), The increase in spike number was a result of greater tiller number which produced more spikes in $\mathrm{D}_{3}$. The number of tiller related to the environmental and genetics factors, because the dynamic of potential tillering ability for cultivar depends on the suitability of environmental factors [16]. Temperature plays important role among the environmental factors which affects tillering phenomenon, prevailing temperature during initiation, growth and development of leaf primordial and its expansion that reflected in the increase leaf node of the stem [17] [18]. The suitable climatic factors such as temperature, light and relative humidity (data not shown) for producing of tillers were exist during this stage in $\mathrm{D}_{3}$ sowing which extended from beginning of full third leaf to the begin of elongation (ZGS13 - ZGS31) which reflected in the hasting emergency, leaf and expansion and perhaps its number. all that was linked with tillers initiation and emergency. The greater number of fertile tillers may be a result of excess of assimilation at tillers production and initiation stage which was very important because the high demand on assimilation that begin to elongate and this tillers, which led to the increase in the CGR (Figure 3 ) and RGR (Figure 5 ).

The hormone play a vital role in the initiation and appearance of tillers and increase the number of fertile tillers [19], Ethylen is released when ethephon is applied to the plants when we applied ethephon $\left(\mathrm{GR}_{2}\right)$. Ethephon is classified as anti- gibberellin, therefore it breaks the apical dominance which in imposed by gibberellin and auxin, hence, causing an increase in the tillers production (Table1) and then the number of fertile tillers, according to [20].

Many previous studies confirmed that the stimulation of tillers emergency after ethephon application was due to the hormonal balance, where the of ethelen from ethephon cause retarding of auxin and gibberellin biosynthesis and their movement in the stem tissues. Due to the cytokinin increase which stimulates the growth of tiller buds [21]. Attya and Jaddoa suggest that the increase in the number of tillers in our study was a result of ethylen action which inhibited auxin action.

Increase the number of tillers in $\mathrm{D}_{2}$ and $\mathrm{D}_{3}$ was due to the low temperature which linked with the hormonal balance, increased ephephon inhibited the apical dominance and retarded the auxin and gibberellin which increases the cytokinin biosynthesis [22].

The greater number of spikes following the application of ethephon and gibberellin was due to increase the number of tillers and increase net photosynthesis, which was reflected in an increasing of CGR, RGR, Dry matter accumulated (Figures 3, 5 and 1) and biomass (Table 2), which supported the growth of spikes from the adequate of photo assimilates. This was confirmed by the statement of [23] and [24] that sufficient assimilate during tillers initiation and development reduce the competition between tillers, leading to the increased fertile tillers (spikes).

The greater number of grains per spike (Table 2) in D3 was due to an increase of spike length (Table 1) and number of spikelet per spike, which this initiation and development coincides the Dry matter accumulated as a result of RGR increase and CGR (Figures 5 and 3), which was effected in 
an increase of spike length and floret number. Consequently, establishing more grain sites in the plants grown in the third sowing $\left(\mathrm{D}_{3}\right)$.

That determine number of grain this was investigated in D3. From that the number of grain per spike genetically controlled and ecological therefore the variation in temperature due to change the planting date effected on determine the number of grain per spike and to realize the potential number for genotype than temperature play a vital role in controlling the hormonal balance within the plant, and probably it had a larger role for the application gibberellin $\left(\mathrm{GR}_{1}\right)$ at $\mathrm{D} 3$ which came increase number of grain (Table 2). According to [25] the apical dominance was controlled by hormones. This might consolidate the probability of increase the grain yield of wheat by synthetic hormones through the control of yield components. It was

possible to delay the growth of median spikelet to provide an adequate time for apical and basal spikelet to reach the right developmental stage, resulting in a synchronous development of all spikelets, therefore, spikes and number of grains per spike were increased. This might be due to the redistribution of assimilates to the sinks [26].

Application of gibberellin caused improvement in sources capacity (increased flag leaf area), this contributes to an increases in assimilation abundance which was invested for the spike and florets growth to compete efficiantelly with the elongated stems [27], This was in agreement with the findings of [28].

\section{Conclusions}

Foliar application of ethephon improved growth characteristics and increased grain yield via the reduction of plant height associated with increased tiller number and consequently spike number and high harvest index. However, gibberellin had reverse effect to that of ethephon. It increased only grain weight with no effect on grain yield. For sowing dates, the highest grain yield was obtained in the plants grown on Nov.18 due to increase spike number, grain of spike and weight of grain compared with the earlier sowing on Oct. 18 which gave the lowest values of grain yield and its components

\section{References}

[1] Darby, B. J, Neher, D. A.; Housman, D. C.; Belnap, J. (2011). Few apparent short-term effects of elevated soil temperature and increased frequency of summer precipitation on the abundance and taxonomic diversity of desert soil micro-and meso-fauna. Soil Biol Biochem 43:1474-1481.

[2] Brown, B. and Walsh, O. S. (2016). Planting Dates in Wheat Production. Bulletin 906. University of Idaho. $10 \mathrm{pp}$.

[3] Thiry, A. D. E.; Sears, R. G.; Shroyer J. P. and Paulsen, G. M. (2002). Relationship between tillering and grain yield of Kansas wheat varieties. Kansas University Agricultural Experiment Station and Cooperative Extension Service, USA. http://oznet. Ksu. Edu.
[4] Lemoine R.; La Camera, S.; Atanassova, R.; Dédaldéchamp, F.; Allario, T.; Pourtau, N.; Bonnemain, J. L.; Laloi, M.; Coutos-Thévenot, P.; Maurousset, L. (2013). Source-to-sink transport of sugar and regulation by environmental factors. Front Plant Sci 4: 272.

[5] Principles of Agronomy, Kalyani. New Delhi-110002. Indiapp:527.[5] Reddy, T. Y. and Reddi, G. H.(2010)

[6] Bijanzadeh, E. and Emam, Y. (2010). Effect of Source-Sink Manipulation on Yield Components and Photosynthetic Characteristic of Wheat Cultivars (Triticum aestivum and T. durum L.). Journal of Applied Sciences, 10: 564-569.

[7] Iqbal, N., R. Nazar, M. Iqbal, R. Khan, A. Masood and N. A. Khan. (2011). Role of gibberellins in regulation of sourcesink relations under optimal and limiting environmental conditions. Current Sci. 100(7):998-1007.

[8] Mohamed, H. H. (2000). Characteristics of the growth, yield and quality of varieties of bread wheat under the influence of planting date. $\mathrm{PhD}$ thesis. College of Agriculture - University of Baghdad - Iraq.

[9] Alyonis, A. A. (1993). production and improvement of field crops, (part 1). cereal crops and legumes. Baghdad of University. College of Agriculture - Iraq. pp: 469.

[10] Assero, S. G. and Tognetti, G. A. (2010). tillering regulations by endogenous and environmental factors and its agricultural managment. The Imericas J. Plant Sci and Biotech, 4 (specialissuel): 935-945.

[11] Van sanford, D. A.; Grove, J. H.; Grabau, L. J. and Mackown, C. T. (1989). Ethephon and nitrogen use in winter wheat. Agro. J. 81: 951-954.

[12] Gai, T.; Xu, H. and Peny, D. (2014). Exogenous hormonal application improves grain yield of wheat by optimizing tiller productivity. Field crop Research. 155: 172-183.

[13] Ramburan, S. (2006). The effect of chlormequat chloride and ethephon on selected small grain cereals in South Africn. M. Sc. Thesis, Agric. Of Sci., Univ. of KWA.

[14] Zadoks, J. C.; Change T. T. and Knozak, C. F. (1974). A decimal code for the growth stages of cereals. Weed Res. 14: 415-421.

[15] Shekoofa, A. and Emam, Y. (2008). Effect of nitrogen fertilization and plant growth regulators (PGRs) on yield of wheat(Triticum aestivum L.) cv. Shiroz. J. Agric. Sci. Technol. 10:101-108.

[16] Bos, H. J and Neuteboom, J. H. (1998). Morphological analysis of leaf and tiller number dynamics of wheat (Triticum aestivum L.): responses to temperature and light intensity. Annals of Botany 81: 131-139.

[17] Equiza M. A. and. Tognetti, J. A. (.2001). Root growth inhibition by low temperature explains differences in sugar accumulation between spring and winter wheat. Aust. J. Plant Physio. 28: 1249-1259.

[18] Equiza, M. A. and Tognetti, J. A.( 2002).. Morphological plasticity of spring and winter wheat under changing temperatures. Funct. Plant Biol. 29: 1427-1436.

[19] Liu, Y.; Chen, W.; Ding, Y.; Wang, Q.; Li, G. and Wang, S. (2012). Effect of gibberellic acid (GA3) and naphthalene acetic acid (NAA) on the growth of unproductive tillers and the grain yield of rice (Oryza sativa L.). African J. Agric. Res. 7(4): 534-539. 
[20] Ma, B. L., and Smith, D. L. (1991). Apical development of spring barley in relation to chloromequat and ethephon. Agro. J. 83: 270-274.

[21] Woodward, E. J. and Marshall, C. (1988). Effect of plant growth regulators and nutrient supply on tiller bud outgrowth in barley (Hordeum distichum L.). Ann. Bot. (London) 61(3): 347-354.

[22] Rajala, A. and Peltonen-Sainio, P.(2001). Plant growth regulator effects on spring cereal root and shoot growth. Agron. J. 93: 936-943.

[23] Al-Hassan, M. F. H. (2007). Pattern and tillering Severability of Five Varieties of Wheat by the Effect of the Sowing Dates and its Relation to Grain and its Components. Master Thesis, Department of Field Crops, College of Agriculture, University of Baghdad.

[24] Nelson, J.( 2000). Shoot morphological plasticity of grasses: leat growth vs tillering In: Lemaire G, Hodgson J, De Moraes A, Cavalho PC de F, Nabinger,C (Eds) Grassland Ecophysiology and Crazing, CBA Internationl, Walling ford. pp 101- 126. Ma, B. L., and D. L. Smith. 1991. Apical development of spring barley in relation to chloromequat and ethephon. Agro. J. 83: 270-274.

[25] Attia, H. G. and Jaddoa, K. A. (1999. Plant Growth Regulators. Theory and Practices. Ministry of Higher Education and Scientific Research. Baghdad- Iraq

[26] Kirby, E. J. M. (1988). Analysis of leaf, stem and ear growth in wheat from terminal spikelet initiation to anthesis. Field Crops Research.,18:127-140.

[27] Cottrell, J. E.; Easton, R. H.; Dale, J. E.; Wadsworth, A. C.; Adam, J. S.; Child R. D. and Hoad, G. V. (1985). A comparison of spike and spikelet survival in main stem and tillers of barley. Anna. Appl. Bio. 106 (2): 365-377.

[28] Chen, L.; Hao, L.; Condon, A. G. and Hu, Y. G. (2014). Exogenous ga3 application can compensate the morphogenetic effects of the ga-responsive dwarfing gene rht12 in bread wheat. plos one 9(1): e86431. doi:10.1371/journal.pone.0086431. 